\title{
HASIL BIMBINGAN TEKNIS PENGEMBANGAN PEMBELAJARAN PADA SMP-RSBI SE-SUMATERA BARAT TAHUN 2010
}

\author{
Elwinetri $^{1}$, Asrizal ${ }^{2}$ \\ ${ }^{1}$ Dinas Pendidikan Pemuda dan Olah Raga Provinsi Sumatera Barat \\ ${ }^{2}$ Jurusan Fisika FMIPA Universitas Negeri Padang
}

\begin{abstract}
ABSTRAK
SBI adalah satuan pendidikan yang diselenggarakan dengan menggunakan Standar Nasional Pendidikan (SNP) dan diperkaya dengan standar salah satu negara anggota OECD atau negara maju lainnya. Mengingat pentingnya kompetensi sumber daya guru yang relevan dengan indikator kinerja SBI baik IKKM maupun IKKT, maka kegiatan untuk meningkatkan kompetensi guru perlu dilakukan. Salah satu alternatif yang dapat dilakukan adalah melalui kegiatan bimtek. Pada kegiatan bimtek instruktur datang ke sekolah untuk membina guru. Secara umum ada dua kegiatan utama yang dilakukan yaitu pengembangan perencanaan pembelajaran dan pelaksanaan pembelajaran. Hasil kegiatan bimtek adalah: 1). Guru mampu menghasilkan perangkat pembelajaran dalam bentuk silabus, RPP, dan bahan ajar yang sesuai dengan standar dan diperkaya dengan bahasa Inggris, ICT, dan sumber belajar dari negara maju, 2). Guru mampu merancang dan menyusun bahan ajar interaktif dengan memanfaatkan sumber belajar dari negara maju melalui internet dan mengoptimalkan sumber belajar yang telah ada, 3). Guru mampu menerapkan sintak suatu model pembelajaran pada langkah pembelajaran dalam RPP yang diperkaya, 4). Guru mampu merancang dan menyusun instrumen penilaian yang diperkaya dengan bahasa Inggris dan model penilaian negara maju pada ranah kognitif, afektif, dan psikomotor, dan 5). Guru MIPA mulai menerapkan proses pembelajaran sesuai dengan standar proses dan diperkaya dengan beberapa indikator kinerja kunci tambahan yang sesuai dengan RSBI yaitu : menggunakan bahasa Inggris dalam pembelajaran, menggunakan sumber belajar berbasis ICT untuk mendukung proses pembelajaran, menggunakan sumber belajar dari negara maju, dan menerapkan model pembelajaran yang relevan dengan negara maju, namun masih ditemukan beberapa kendala.
\end{abstract}

Kata kunci: SBI, SNP, Pengayaan (X), OECD, IKKM, IKKT

\section{PENDAHULUAN}

Era globalisasi menuntut kemampuan daya saing yang kuat dalam teknologi, manajemen dan sumberdaya manusia. Keunggulan teknologi akan menurunkan biaya produksi, meningkatkan kandungan nilai tambah, memperluas keragaman produk, dan meningkatkan mutu produk. Keunggulan manajemen dapat mempengaruhi dan menentukan baik tidaknya kinerja sekolah. Kenggulan sumber daya manusia (SDM) yang memiliki daya saing tinggi pada tingkat internasional akan menjadi daya tawar tersendiri dalam era globalisasi ini (Edy, S: 2006).

Dalam upaya peningkatan mutu, efisiensi, relevansi, dan peningkatan daya saing secara nasional dan internasional pada jenjang pendidikan dasar dan menengah, maka telah ditetapkan pentingnya penyelenggaraan pendidikan bertaraf internasional, baik untuk sekolah negeri maupun swasta. Berkaitan dengan penyelenggaraan pendidikan yang bertaraf internasional ini, maka: (1) pendidikan bertaraf internasional yang bermutu adalah pendidikan yang mampu mencapai standar mutu nasional dan internasional, (2) pendidikan bertaraf internasional yang efisien adalah pendidikan yang menghasilkan standar mutu lulusan optimal baik maupun internasional dengan pembiayaan yang minimal, (3) pendidikan bertaraf internasional juga harus relevan, yaitu bahwa penyelenggaraan pendidikan harus disesuaikan dengan kebutuhan peserta didik, orang tua, masyarakat, kondisi lingkungan, kondisi sekolah, dan kemampun 
pemerintah daerahnya; dan (4) pendidikan bertaraf internasional harus memiliki daya saing yang tinggi dalam hal hasil-hasil pendidikan (output dan outcomes), proses, dan input sekolah baik secara nasional maupun internasional (Sri, RW: 2009).

Era globalisasi yang sudah memasuki dunia pendidikan, menuntut sekolah untuk mampu melakukan berbagai upaya untuk menciptakan lulusan yang berdaya saing global (Edi, K: 2006). Arah dasar pendidikan dalam budaya global harus mampu mencakup aspek pengetahuan, keterampilan, pembentukan karakter, dan internalisiasi nilai-nilai dasar hidup manusia. Dengan dasar ini pemerintah melalui Derektorat Pendidikan Menengah Umum membuat program Sekolah Bertaraf Internasional (SBI). Menurut UU nomor 20 tahun 2003, pasal 50 ayat 3 "Pemerintah dan/ atau Pemerintah daerah menyelenggarakan sekurangkurangnya satu satuan pendidikan yang bertaraf internasional" (Reni, M: 2011). Sebagai implementasi dari UU ini telah dilakukan uji coba SBI pada sekolah-sekolah konvensional.

Sekolah Bertaraf Internasional (SBI) adalah satuan pendidikan yang diselenggarakan dengan menggunakan Standar Nasional Pendidikan (SNP) dan diperkaya dengan standar salah satu negara anggota Organizatian for Economic Co-operation and Development (OECD) dan/atau negara maju lainnya (Sungkowo : 2009). Dengan ungkapan lain, SBI adalah sekolah yang sudah memenuhi dan melaksanakan Standar Nasional Pendidikan (SNP) yang meliputi delapan standar yaitu: standar isi, standar proses, standar kompetensi lulusan, standar pendidik dan tenaga kependidikan, standar sarana dan prasarana, standar pengelolaan, standar pembiayaan, dan standar penilaian. Selanjutnya aspek-aspek SNP tersebut diperkaya, diperkuat, dikembangkan, diperdalam, dan diperluas melalui adaptasi atau adopsi standar pendidikan dari salah satu anggota OECD atau negara maju lainnya yang mempunyai keunggulan tertentu dalam bidang pendidikan serta diyakini telah memiliki reputasi kualitas yang diakui secara internasional, serta lulusannya memiliki kemampuan daya saing internasional (Gusti, A: 2011).

Melalui cara ini, diharapkan SBI harus mampu memberikan jaminan bahwa baik dalam penyelenggaraan maupun hasil-hasil pendidikannya lebih tinggi standarnya daripada SNP. Penjaminan ini dapat ditunjukkan kepada masyarakat nasional maupun internasional melalui berbagai strategi yang dapat dipertanggung jawabkan.

Sesuai dengan konsep SBI, maka dalam upaya mempermudah sekolah dalam memahami dan menjabarkan secara operasional dalam penyelenggraan pendidikan yang mampu menjamin kualitasnya bertaraf internasional, maka dapat dirumuskan bahwa SBI pada dasarnya merupakan pelaksanaan dan pemenuhan delapan unsur SNP sebagai Indikator Kinerja Kunci Minimal (IKKM) dan diperkaya dengan x yang isinya merupakan penambahan (pengayaan, pendalaman, penguatan, perluasan) dari delapan unsur pendidikan serta sistem lain sebagai Indikator Kinerja Kunci Tambahan (IKKT) yang berstandar internasional dari salah satu anggota OECD atau negara maju lainnya (Krisna: 2011).

Dalam kerangka pencapaian standar mutu internasional, maka tiap sekolah yang telah menjadi RSBI atau SBI harus memenuhi IKKM dan IKKT. IKKM merupakan indikator untuk memenuhi delapan unsur SNP, sedangkan IKKT merupakan indikator yang berhubungan dengan pengayaan yang relevan dengan negara-negara maju (Krisna: 2011).

Adapun tujuan dari SBI secara garis besar terbagi menjadi dua, yaitu tujuan umum dan khusus. Tujuan umum adalah untuk meningkatkan kualitas pendidikan nasional sesuai dengan amanat Tujuan Pendidikan Nasional dalam Pembukaan UUD 1945, pasal 31 UUD 1945, UU No. 20 tahun 2003 tentang Sisdiknas, PP No.19 tahun 2005 tentang SNP, memberi kesempatan pada sekolah yang berpotensi untuk mencapai kualitas bertaraf nasional dan internacional, dan menyiapkan lulusan yang mampu berinteraksi secara progresif dalam masyarakat internasional. Adapun tujuan khusus, adalah menyiapkan lulusan yang memiliki kompetensi 
Prosiding Seminar Nasional

HFI Cabang Sumatera Barat

Padang, 28-29 Juli 2011

ISBN 978-602-19069-0-3

sesuai dengan standar nasional ditambah dengan standar lulusan berciri internasional (Reni, M: 2011).

Suatu SBI memiliki karakteristik tertentu sehingga berbeda dengan sekolah lainnya pada tingkat Sekolah Standar Nasional (SSN). Ada tujuh karakteristik SBI yaitu: 1) sekolah menerapkan Kurikulum Tingkat Satuan Pendidikan (KTSP) yang dikembangkan dari standar isi, standar kompetensi kelulusan, dan kompetensi dasar yang diperkaya dengan muatan internasional, 2) menerapkan proses pembelajaran dalam bahasa Inggris, minimal untuk mata pelajaran Matematika, Ilmu Pengetahuan Alam, dan Bahasa Inggris, 3) mengadopsi buku teks yang dipakai SBI dari negara maju, 4) menerapkan standar kelulusan yang lebih tinggi dari standar kompetensi lulusan (SKL) yang ada di dalam SNP, 5) pendidik dan tenaga kependidikan memenuhi standar kompetensi yang ditentukan dalam SNP, 6) sarana dan prasarana memenuhi SNP, dan 7) penilaian memenuhi standar nasional dan internasional. Dengan adanya tujuh karakteristik ini menjadikan SBI lebih unggul dari sekolah lainnya (Imam, G: 2009).

Untuk dapat memenuhi karakteristik dari konsep SBI tersebut, yaitu sekolah telah melaksanakan dan memenuhi delapan unsur SNP sebagai pencapaian IKKM ditambah dengan (x) sebagai IKKT, maka sekolah dapat melakukan minimal dengan dua cara yaitu adaptasi dan adopsi. Adaptasi, yaitu penyesuaian unsur-unsur tertentu yang sudah ada dalam SNP dengan mengacu pada standar pendidikan salah satu anggota OECD atau negara maju lainnya yang mempunyai keunggulan tertentu dalam bidang pendidikan, diyakini telah memiliki reputasi kualitas yang diakui secara internasional, serta lulusannya memiliki kemampuan daya saing internasional. Disisi lain adopsi, yaitu penambahan (pengayaan, pendalaman, penguatan, perluasan) dari unsur-unsur tertentu yang belum ada diantara delapan unsur SNP dengan tetap mengacu pada standar pendidikan salah satu anggota OECD atau negara maju lainnya yang mempunyai keunggulan tertentu dalam bidang pendidikan, diyakini telah memiliki reputasi mutu yang diakui secara internasional, serta lulusannya memiliki kemampuan daya saing internasional (Didik, S: 2010).

Karakteristik visi SBI adalah "terwujudnya insan Indonesia yang cerdas dan kompetitif secara internasional". Visi tersebut memiliki implikasi bahwa penyiapan manusia bertaraf internasional memerlukan upaya-upaya yang dilakukan secara intensif, terarah, terencana, dan sistematik agar dapat mewujudkan bangsa yang maju, sejahtera, damai, dihormati, dan diperhitungkan oleh bangsa-bangsa lain. Dengan dasar ini, misi SBI adalah mewujudkan manusia Indonesia cerdas dan kompetitif secara internasional, yang mampu bersaing dan berkolaborasi secara global (Fandalarasati: 2009). Dengan visi dan misi ini diharapkan SBI menghasilkan lulusan yang unggul.

Dengan merujuk pada buku panduan sistem penyelenggaraan SBI dari Depdiknas dan mempertimbangkan kondisi nyata saat ini, maka rencana pengembangan SBI dirancang melalui tiga fase yaitu fase rintisan, fase konsolidasi, dan fase kemandirian (Yoyon, B.I: 2011). Pada fase rintisan sekolah didampingi oleh tenaga dari lembaga profesional independent atau lembaga terkait dalam melakukan persiapan, penyusunan dan pengembangan kurikulum, penyiapan SDM, modernisasi manajemen dan kelembagaan, pembiayaan, serta penyiapan sarana prasarana. Pada konsolidasi, sekolah melakasanakan dan meningkatkan kualitas hasil yang sudah dikembangkan pada tahap pendampingan. Dalam proses ini hal terpenting adalah dilakukannya refleksi terhadap pelaksanaan kegiatan untuk keperluan penyempurnaan serta realisasi program kemitraan dengan sekolah mitra dalam dan luar Negeri serta lembaga sertifikasi pendidikan internasional. Pada fase mandiri, sekolah sudah berubah dari RSBI menjadi SBI dengan semua profil yang diharapkan telah tercapai. 
Untuk menuju kepada satuan pendidikan yang bertaraf internasional atau SBI tersebut, maka pemerintah sejak tahun 2007 telah melaksanakan pembinaan kepada sekolah untuk dikembangkan menjadi satuan pendidikan bertaraf internasional. Satuan pendidikan ini dikenal dengan rintisan Sekolah Bertaraf Internasional yang disingkat dengan RSBI. Dikatakan sebagai rintisan adalah sekolah-sekolah tersebut dipersiapkan secara bertahap melalui pembinaan oleh pemerintah dan stakeholder dalam jangka waktu tertentu yaitu empat tahun diharapkan sekolah tersebut mampu dan memenuhi kriteria untuk menjadi SBI (Didik, S: 2010).

Mengingat pentingnya kompetensi sumber daya guru yang relevan dengan indikator kinerja RSBI, maka kegiatan untuk meningkatkan kompetensi guru perlu dilakukan. Salah satu alternatif yang dapat dilakukan adalah melalui kegiatan bimbingan teknis (bimtek). Untuk itu Pemerintah provinsi Sumatera Barat melalui Dinas Pendidikan Pemuda dan Olah raga melaksanakan kegiatan bimtek bagi guru MIPA, Bahasa Inggris, dan ICT. Kegiatan bimtek dilaksanakan dalam bentuk inhouse training. Ada beberapa keunggulan yang dapat diperoleh melaui bimtek in-house training ini antara lain: kegiatan dapat dilakukan tanpa mengganggu proses pembelajaran, bimbingan kegiatan dapat lebih intensif, kegiatan dapat mengatasi permasalahan-permasalah langsung di sekolah, dapat mengoptimalkan peralatan dan sarana yang ada di sekolah, dan sebagainya.

\section{METODE PELAKSANAAN}

Kegiatan bimtek terhadap guru MIPA, Bahasa Inggris dan ICT SMP-RSBI Provinsi Sumatera Barat tahun anggaran 2010 dilaksanakan mulai dari bulan Juni sampai Nopember 2010. Tempat pelaksanaannya adalah di sekolah SMP-RSBI bersangkutan. Dalam hal ini instruktur berkunjung ke sekolah memberikan materi sesuai dengan program yang sudah ditentukan oleh panitia bimtek. Kunjungan dilaksanakan sebanyak 12 kali pertemuan. Untuk satu kali pertemuan dilaksanakan selama 18 jam.

Sebagai sasaran dalam kegiatan bimtek ini adalah guru-guru MIPA, Bahasa Inggris dan ICT pada SMP-RSBI Propinsi Sumatera Barat. Sesuai dengan jadwal yang diberikan pada kegiatan bimtek ini ada 7 SMP-RSBI sebagai sasaran kegiatan yaitu: SMP Negeri 1 Padang, SMP Negeri 8 Padang, SMP Negeri 1 Pariaman, SMP Negeri 1 Payakumbuh, SMP Negeri 1 Lubuk Sikaping, SMP Negeri 2 Gunung Talang, dan SMP Negeri 1 Rambatan.

Model pelaksanaan kegiatan bimtek pada pengembangan perencanaan pembelajaran meliputi: presentasi oleh instruktur, pemberian model oleh instruktur, diskusi tentang materi dan model pembelajaran, latihan terstruktur untuk untuk menghasilkan produk kegiatan, latihan terbimbing untuk menyelesaikan sampel produk, latihan mandiri untuk menyelesaikan produk dan menyerahkan produk kegiatan. Disisi lain, metode yang digunakan untuk materi observasi proses pembelajaran (Real Teaching) di kelas adalah: pengamatan proses pembelajaran di kelas dengan menggunakan instrumen observasi pembelajaran, refleksi pembelajaran di kelas oleh guru model, teman sejawat, dan instruktur, diskusi rencana tindak lanjut, dan pemberian wawasan tambahan

\section{HASIL DAN DISKUSI}

Melalui kegiatan bimtek untuk meningkatkan kompetensi guru-guru MIPA, ICT, dan Bahasa Inggris pada SMP-RSBI dihasilkan beberapa produk kegiatan. Sebagai produk kegiatan adalah silabus dan RPP, bahan ajar, implementasi model pembelajaran pada RPP, instrumen evaluasi, dan dokumentasi dan catatan kegiatan observasi kelas dan refleksi. 


\section{Hasil Revisi Silabus dan RPP Dalam Bahasa Inggris}

Silabus dan RPP merupakan komponen yang penting dalam perencanaan pembelajaran. Silabus adalah rencana pembelajaran pada suatu dan/atau kelompok mata pelajaran/tema tertentu yang mencakup standar kompetensi, kompetensi dasar, materi pokok/pembelajaran, kegiatan pembelajaran, indikator pencapaian kompetensi untuk penilaian, penilaian, alokasi waktu, dan sumber belajar. Rencana pelaksanaan pembelajaran merupakan rancangan secara menyeluruh kegiatan pembelajaran yang harus dilakukan peserta didik dalam kegiatan pembelajaran untuk mencapai kompetensi yang telah ditetapkan, dan strategi pembelajaran serta penilaian yang akan dilakukan oleh guru dalam proses pembekalan kompetensi peserta didik.

Pada waktu kegiatan bimtek diketahui beberapa kelemahan dari silabus dan RPP yang dimiliki guru. Sebagai contoh silabus dan RPP sebagian dalam bahasa Indonesia, belum dikembangkan sesuai dengan kondisi sekolah, beberapa komponen dari RPP yang belum sinkron, dan belum diperkaya dengan indikator yang relevan dengan negara-negara maju; kurangnya kesesuaian antara tujuan dengan indikator dan kompetensi dasar, kesesuaian metode dengan skenario pembelajaran; kurang tepatnya penjabaran langkah-langkah kegiatan inti

Pada kegiatan bimtek guru diberi wawasan singkat tentang pengembangan silabus dan RPP yang sesuai dengan standar depdiknas dan diperkaya dengan indikator kinerja kunci tambahan yang relevan dengan negara-negara maju. Kemudian dilakukan kegiatan diskusi dan bimbingan untuk mengembangkan silabus dan RPP yang sesuai dengan standar dan diperkaya.

Melalui kegiatan bimtek, guru-guru merevisi silabus yang sesuai dengan standar diperkaya dengan beberapa indikator kinerja kunci tambahan. Ada empat pengayaan yang diberikan pada silabus yaitu: indikator ditambah, materi diperkaya dalam bentuk aplikasi, ditulis dalam bahasa Inggris, dan menggunakan sumber belajar atau referensi dari negara-negara maju.

Melalui kegiatan bimtek guru juga merevisi RPP yang dimiliki. Revisi dilakukan dengan mengacu pada format standar, menyesuaikan antara tujuan dengan indikator dan kompetensi dasar. Disamping itu diberikan pula pengayaan terhadap RPP yang telah ada seperti penulisan dalam bahasa Inggris atau menyempurnakan kesalahan dalam grammar, materi pembelajaran dalam bentuk aplikasi, dan sumber belajar dari negara-negara maju. Sampel hasil revisi silabus dan RPP untuk mata pelajaran IPA diperlihatkan pada Gambar 1.

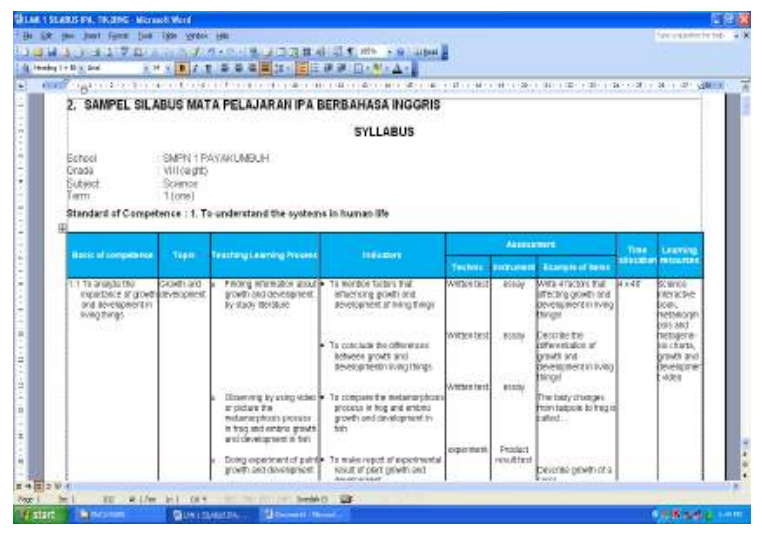

Gambar 1a. Sampel Silabus Diperkaya 


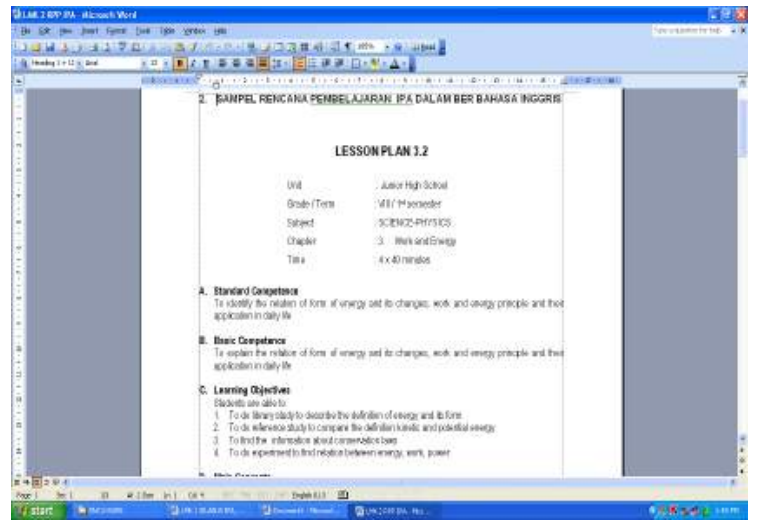

Gambar 1b. Sampel RPP Diperkaya

\section{Hasil Penyusunan Bahan Ajar Dalam Bahasa Inggris}

Bahan ajar merupakan bagian penting dalam pelaksanaan pendidikan di sekolah. Bahan ajar merupakan seperangkat materi yang disusun secara sistematis sehingga tercipta lingkungan/suasana yang memungkinkan siswa untuk belajar. Melalui bahan ajar guru akan lebih mudah dalam melaksanakan pembelajaran dan siswa akan lebih terbantu dan mudah dalam belajar. Bahan ajar dapat dibuat dalam berbagai bentuk sesuai dengan kebutuhan dan karakteristik materi ajar yang akan disajikan.

Dari hasil pengamatan pada waktu kegiatan bimtek penyusunan bahan ajar dapat dikemukakan bahwa umumnya guru belum memiliki bahan ajar yang dibuat sendiri. Sebagai buku pegangan guru dan siswa yang dimiliki oleh guru dalam bentuk buku teks dalam bahasa Inggris dan buku bilingual. Disisi lain buku pegangan yang dimiliki siswa adalah dalam bentuk buku bilingual. Kenyataan ini menunjukkan bahwa guru masih lemah dalam menghasilkan bahan ajar.

Tindakan yang dilakukan untuk merancang dan menyusun bahan ajar yang dilakukan meliputi: menganalisis SK dan KD, memilih salah satu bentuk bahan ajar, menulis bahan ajar, dan menyelesaikan sampel produk dari bahan ajar. Ada tiga model bahan ajar yang disusun dalam kegiatan bimtek yaitu: modul, media presentasi, dan bahan kompilasi. Hal ini tergantung kepada arahan dan bimbingan dari masing-masing nara sumber. Pengayaan yang diberikan terhadap bahan ajar antara lain: penggunaan bahasa Inggris, materi dalam bentuk aplikasi, multimedia interaktif, dan sumber belajar dari negara-negara maju.

Melalui kegiatan bimtek penyusunan bahan ajar telah dihasilkan tiga variasi bahan ajar menggunakan bahasa Inggris dan ICT yaitu media presentasi interaktif, bahan ajar kompilasi interaktif, dan lembaran kerja siswa interaktif. Susunan penulisan setiap bahan ajar tergantung kepada bahan ajar yang dipilih. Sampel produk bahan ajar dalam bentuk bahan ajar kompilasi dan lembaran kerja siswa interaktif dapat diperhatikan pada Gambar 2. 


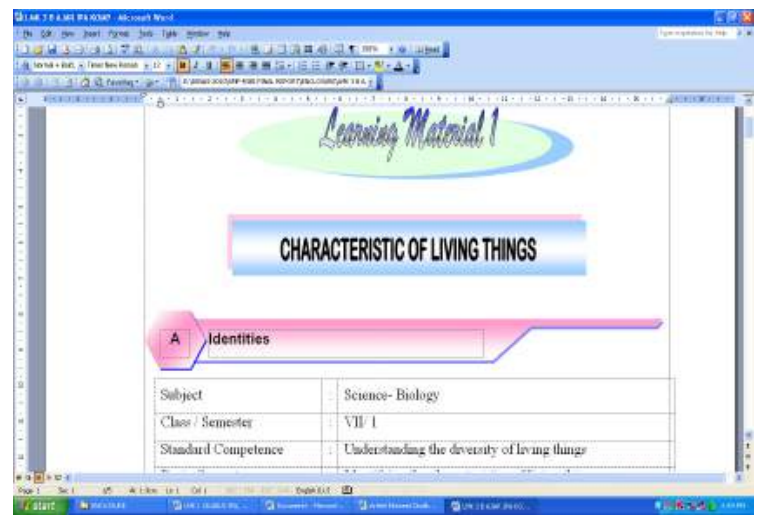

Gambar 2a. Sampel Bahan Ajar Kompilasi Interaktif

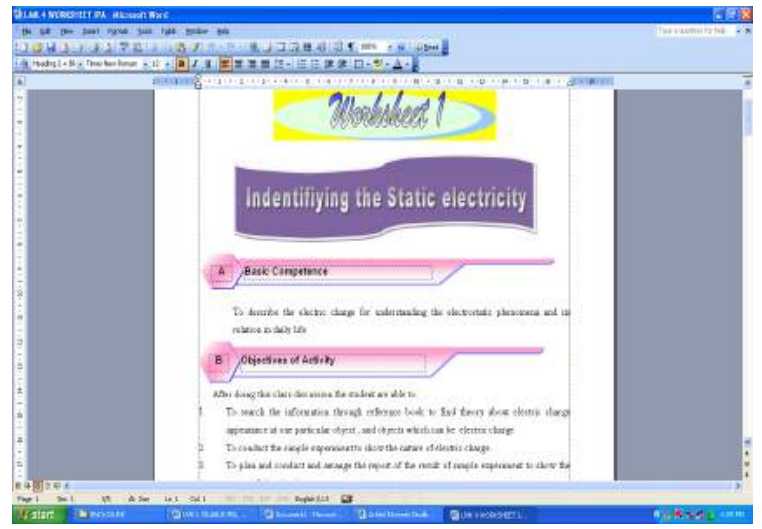

Gambar 2b. Sampel Lembaran Kerja Siswa Interaktif

\section{Hasil Implementasi Model Pembelajaran Pada RPP}

Kegiatan pembelajaran pada kegiatan inti merupakan proses pembelajaran untuk mencapai KD yang dilakukan secara interaktif, inspiratif, menyenangkan, menantang, memotivasi peserta didik untuk berpartisipasi aktif, serta memberikan ruang yang cukup bagi prakarsa, kreativitas, dan kemandirian sesuai dengan bakat, minat dan perkembangan fisik serta psikologis peserta didik. Untuk mewujudkan ini diperlukan pembelajaran dengan multimedia, multi metoda, dan multi strategi. Untuk itu, impementasi model pembelajaran penting untuk mencapai tujuan pembelajaran.

Berdasarkan hasil pengamatan awal kegiatan bimtek model pembelajaran ditemukan beberapa kenyataan yaitu: sebagian guru belum mengenal tentang model pembelajaran, sebagian guru telah mengenal model pembelajaran tetapi belum memahami konsep untuk membangun sebuah model, sebagian guru belum memahami langkah-langkah dari suatu model pembelajaran, masih banyak guru yang menggunakan metode ceramah dalam pelaksanaan kegiatan pembelajaran. Hal ini diperkuat dengan kenyataan bahwa langkah-langkah suatu model pembelajaran belum terlihat pada skenario pembelajaran pada RPP.

Kegiatan bimtek memberikan pemahaman tentang model pembelajaran, kelompok model pembelajaran, konsep membangun suatu model pembelajaran, contoh-contoh model pembelajaran inovatif, dan contoh aplikasi suatu model pembelajaran dalam RPP. Instruktur memberikan informasi singkat tentang model, membimbing peserta untuk mengaplikasi model pembelajaran pada RPP, dan meminta peserta untuk menyiapkan produk kegiatan dalam 
bentuk implementasi model pembelajaran dalam RPP. Indikator pengayaan yang diberikan dalam kegiatan bimtek antara lain: penggunaan bahasa Inggris, sumber belajar berbasis ICT, materi dalam bentuk aplikasi dan relevansi dengan ilmu lain, buku referensi dalam bahasa Inggris, dan model pembelajaran yang relevan dengan nagara maju.

Melalui kegiatan bimtek dihasilkan produk kegiatan dalam bentuk RPP yang memuat model pembelajaran. Peserta memilih salah satu model pembelajaran yang sesuai dengan kompetensi dasar dan indikator, menentukan pendekatan pembelajaran dan metode yang digunakan, dan menjabarkan sintak dari suatu model pembelajaran dalam langkah kegiatan pembelajaran.

\section{Hasil Penyusunan Instrumen Penilaian}

Penilaian merupakan bagian yang tidak terpisahkan dari proses pembelajaran secara keseluruhan. Penilaian yang dilakukan guru dalam kegiatan belajar sehari-hari (classroom assesment) yang menjamin terjadinya peningkatan mutu pembelajaran secara berkelanjutan. Salah satu penilaian yang dapat meningkatkan mutu pendidikan adalah penilaian kelas. Keberhasilan pembelajaran tergantung kepada efektivitas penilaian kelas yang dilakukan. Penilaian kelas yang baik mampu memberikan informasi yang bermanfaat bagi guru untuk meningkatkan efektivitas mengajarnya dan bagi peserta didik untuk meningkatkan mutu kegiatan dan hasil belajarnya.

Pada awalnya guru terlihat guru mengalami kesulitan dalam merancang alat evaluasi terutama dalam menggunakan bahasa Inggris. Kegiatan diawali dengan presentasi nara sumber tentang sistem penilaian. Kemudian peserta diminta secara berkelompok merancang alat evalusi dimulai dari analisis $\mathrm{SK} / \mathrm{KD}$, pembuatan kisi-kisi dan penulisan alat penilaian berbahasa Inggris. Alat penilaian dibuat dalam bentuk objective test. Pada sesi ini dihasilkan alat evaluasi berbahasa Inggris untuk kelas VII, VIII dan IX.

Melalui kegiatan bimtek diberikan indikator pengayaan seperti: instrumen evaluasi dalam bahasa Inggris, kesesuaian antara indikator dengan instrumen, dan penilaian dalam bentuk autentik. Produk kegiatan bimtek dalam bentuk instrumen penilaian autentik yang terdiri dari instrumen penilaian kognitif, afektif, dan psikomotor.

\section{Hasil Observasi Real Teaching}

Suatu kegiatan observasi pembelajaran di kelas adalah mengamati dan mempelajari suatu proses belajar mengajar di kelas untuk menentukan strategi pembelajaran yang tepat dan tingkat tanggapan siswa. Kegiatan ini dapat digunakan untuk mengumpulkan masukan untuk perencanaan, pengorganisasian, pendekatan, metode presentasi, teknik pengelolaan prilaku, dan mengenal perbedaan siswa secara individu. Tujuan dari kegiatan observasi pembelajaran adalah untuk strategi dan model yang efektif, mengidentifikasi masalah potensial, dan menemukan solusi yang mungkin dilakukan. Dengan cara ini observasi dapat digunakan untuk merencanakan strategi ke depan, memasukkan teknik baru pada koleksi metode dan model pembelajaran, dan mempersiapkan pendekatan bagi situasi yang bermasalah.

Pada kegiatan ini dilakukan observasi proses pembelajaran di kelas oleh nara sumber dan teman sejawat. Narasumber melakukan pengamatan dengan menggunakan instrumen pengamatan kegiatan pembelajaran. Instrument tersebut memuat beberapa kegiatan yang mesti dilakukan oleh guru berupa kegiatan pendahuluan, kegiatan inti, dan kegiatan penutup. Kegiatan pembelajaran mengacu kepada Permendiknas No. 41 yang berkenaan dengan Standar Proses pembelajaran yang memuat tiga fase kegiatan inti yaitu: Eksplorasi, Elaborasi dan Konfirmasi. 
Pada kegiatan observasi kelas nara sumber juga mengamati indikator kinerja tambahan yang diimplementasikan oleh guru seperti: implementasi bahasa Inggris dalam pembelajaran secara efektif, penggunaan sumber belajar berbasis ICT untuk mendukung proses pembelajaran, penggunaan model pembelajaran yang sesuai dengan karakteristik kompetensi dasar dan indikator, penggunaan media atau peralatan untuk mendukung proses pembelajaran, penggunaan bahan ajar untuk mengaktifkan siswa belajar, dan sebagainya.

Setelah proses pembelajaran di kelas dilakukan kegiatan refleksi terhadap pelaksanaan pembelajaran. Kegiatan refleksi dipimpin oleh instruktur. Refleksi dilakukan oleh guru model, teman sejawat yang melakukan observasi, dan oleh instruktur. Kegiatan refleksi terdiri dari beberapa tahap yaitu: pembukaan oleh nara sumber, refleksi oleh guru model, refleksi oleh teman sejawat, refleksi oleh nara sumber, diskusi rencana perbaikan dan tindak lanjut, dan penutup oleh nara sumber.

Produk dari observasi proses pembelajaran dalam bentuk: catatan lapangan, hasil rekaman pembelajaran di kelas, dan catatan hasil refleksi. Salah satu proses pembelajaran di SMP Negeri 1 Payakumbuh diperlihatkan pada Gambar 3

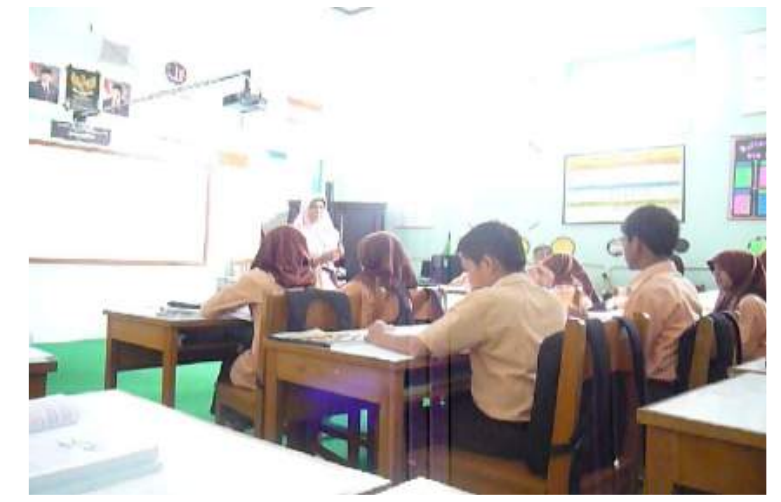

Gambar 3a. Guru Mengarahkan Siswa Untuk Bekerja Dalam Kelompok

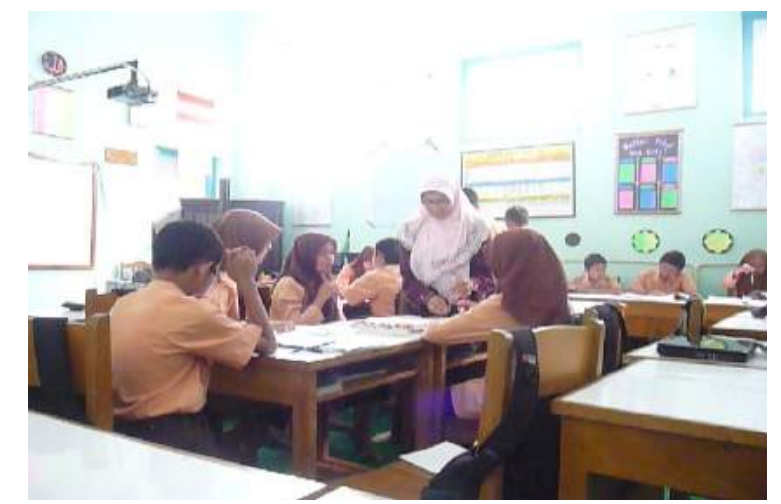

Gambar 3b. Guru Membimbing Siswa Bekerja Dalam Kelompok

\section{KESIMPULAN}

Berdasarkan pelaksanaan dan hasil yang dicapai dalam kegiatan bimtek dapat dikemukakan beberapa kesimpulan sebagai berikut: 
1. Guru telah mampu menghasilkan sampel perangkat pembelajaran dalam bentuk silabus, RPP, dan bahan ajar yang sesuai dengan standar dan diperkaya dengan bahasa Inggris, ICT, sumber belajar dari negara maju.

2. Guru mampu merancang dan menyusun bahan ajar dalam bentuk media presentasi, bahan ajar kompilasi, dan lembaran kerja siswa interaktif dengan memanfaatkan sumber belajar dari negara maju melalui internet dan mengoptimalkan sumber belajar yang telah dimiliki guru.

3. Guru telah mampu menerapkan sintak dari suatu model pembelajaran pada langkahlangkah pembelajaran dalam RPP yang diperkaya.

4. Guru mampu merancang dan menyusun instrumen penilaian yang diperkaya dengan bahasa Inggris dan model penilaian negara maju baik dalam ranah kognitif, afektif, maupun psikomotor.

5. Guru IPA telah mulai menerapkan proses pembelajaran sesuai dengan standar proses dan diperkaya dengan beberapa indikator kinerja kunci tambahan yang sesuai dengan RSBI yaitu : menggunakan bahasa Inggris dalam pembelajaran, menggunakan sumber belajar berbasis ICT untuk mendukung proses pembelajaran, menggunakan sumber belajar dari negara maju, dan menerapkan model pembelajaran yang relevan dengan negara maju, namun masih ditemukan beberapa kendala.

\section{DAFTAR PUSTAKA}

Adi Wijaya, (2009). Konsep Sekolah Bertaraf Internasional. http://adifia. wordpress. com/2009/11/12/konsep-sekolah-bertaraf-internasional-sbi/

Didik Suhardi, (2010). Panduan Pelaksanaan Penyelenggaraan Sekolah Bertaraf Internasional Pada Jenjang SMP. Kementrian Pendidikan Nasional Direktortat Jenderal Manajemen Pendidikan Dasar dan Menengah Direktorat Pembinaan Sekolah Menengah Pertama.

Didik Suhardi, (2010). Panduan Pelaksanaan Pembinaan SMP Rintisan Sekolah Bertaraf Internasional (SMP-RSBI). Kementrian Pendidikan Nasional Direktortat Jenderal Manajemen Pendidikan Dasar dan Menengah Direktorat Pembinaan Sekolah Menengah Pertama.

Eddy Kusnadi, (2006). SNBI Suatu Alternatif Di Persaingan Global. Lembaga Perguruan Taman Taruna Nusantara. http://taruna-nusantara-mgl.sch.id/id2/ index. php? option=com content\&task=view\&id=103\&Itemid=1

Edy Supriyadi, (2009). Peran Perguruan Tinggi Dalam Menyiapkan Calon Guru Sekolah Bertaraf Internasional. Dosen Jurusan Pendidikan Teknik Elektro FT. UNY

Fandalarasati, (2009). Analisa Kebijakan Pendidikan tentang Sekolah Berstandar International. Pascasarjana UPI. http://fandalarasati. wordpress. com/ artikel/analisakebijakan-pendidikan-tentang-sekolah-berstandar- international/

Gusti Astika, (2011). Model Kelas Bilingual di Sekolah Bertaraf Internasional: Sebuah Pemikiran Konseptual. Guru Pembaharu. Com. http:// guru pembaharu. com/home/?p=2733

Imam Gunawan, (2009). Strategi Pengembangan Sekolah Bertaraf Internasional. http://masimamgun.blogspot.com/2009/12/strategi-pengembangan-sekolahbertaraf.html

Krisna, (2011). Konsep SBI dan RSBI. http://krisna1.blog. uns.ac.id/2011/01/01/ konsep-sbidan-rsbi/ 
Reni Marlinawati, (2011). Optimalisasi Prinsip Pendidikan dalam Mengejar Kualitas Standar Pendidikan Internasional. http://renimarlinawati.com/ index. php? option=com_content\&view=article\&id=303:optimalisasi-prinsip-pendidikan-dalammengejar-kualitas-standar-pendidikan-internasional- $\&$ catid=54:pendidikan $\&$ Itemid=89

Sri Rini Wahyuni, (2009). Konsep SBI pada jenjang pendidikan SMP. http:// sririniwahyuni.blogspot.com/2009/08/konsep-sbi-pada-jenjang-pendidikan-smp.html

Sungkowo, (2009). Panduan Penyelenggaraan Program Rintisan SMA Bertaraf Internasional $(R-S M A-B I)$. Departemen Pendidikan Nasional Direktorat Jenderal Manajemen Pendidikan Dasar Dan Menengah Direktorat Pembinaan Sekolah Menengah Atas

Yoyon Bahtiar Irianto, (......). Membangun Sekolah Bertaraf Internasional. Ketua Tim Konsultan Pengembang SBI Kabupaten Sukabumi dan Kabupaten Majalengka. http://file.upi.edu/Direktori/FIP/Jur._Administrasi_Pendidikan/196210011991021Yoyon_Bahtiar_Irianto/Membangun_Madrasah_Bertaraf_Internasional.pdf 